\title{
Towards Responsible and Sustainable Supply Chains - Innovation, Multi-stakeholder Approach and Governance
}

\author{
Agata Gurzawska ${ }^{1}$
}

Published online: 13 June 2019

(C) The Author(s) 2019

\begin{abstract}
Supply chains are an indispensable element of any global economy. At the same time such supply chains create a societal and environmental burden. Drastic actions are required to mitigate these effects. Supply chains should become responsible and sustainable (where responsibility and sustainability are understood in a broad sense) addressing economic, political, societal, legal, human rights, ethical and environmental concerns. This research shifts from the question of why companies should implement responsibility and sustainability into supply chains, to how they should do so effectively. Illustrated by a case study of Sedex, a collaborative platform for buyers and suppliers, this paper proposes three solutions for responsible and sustainable supply chain management (SCM). Firstly, supply chains have to be supported by research and innovation (R\&I). Secondly, supply chains should be based on multi-stakeholder efforts of industry, governmental and non-governmental organisations. Thirdly, the responsibility should lie not only with an individual company and its employees, but also with organisations of companies (supra-agency). As a result, responsible and sustainable supply chains require technological, political and ethical solutions involving the development of sound, multi-stakeholder business and governance models. These models should be based on the equal consideration of all three dimensions of sustainability (economic, environmental and social), the cooperation of the partners in the chain, strengthening long-term relationships and legitimate requirements of the stakeholders of a supply chain.
\end{abstract}

Keywords Supply chain management (SCM) - Responsible and sustainable supply chains · Innovation · Multi-stakeholder approach $\cdot$ Non-state actor regimes $\cdot$ Governance models

Agata Gurzawska

a.m.gurzawska@utwente.nl

1 Department of Philosophy, Faculty of Behavioural Sciences, University of Twente, P.O. Box 217, 7500 AE Enschede, The Netherlands 


\section{Introduction}

Today's global economy is based on dynamic and complex networks of businesses known as supply chains. Thanks to supply chain businesses, suppliers, products and services can be provided to consumers. Supply chain management (SCM) helps to organise this flow of goods and service and to manage complex relationships among manufacturers, intermediaries, and end users. SCM also provides means of developing competitive advantage and positioning strategy.

Along with globalisation of economies, SCM is generating considerable interest in terms of responsibility and sustainability. As supply chains grow and become complex and unclear networks, they increasingly become more difficult to be managed. These challenges are driven to a greater extent by difficulties in identifying resource scarcity, population growth and continuing urbanisation, market developments and internationalisation, shifting consumption patterns, technological advances and disruption risks. Increasingly, the production processes are broken down into various distinct activities that are organised and performed in distinct locations spread across different countries or regions (Rangi et al. 2015 ${ }^{1}$ ). With global supply chains, companies aim to take advantage of differences across places in terms of, for example, technological development, legal regulations, workforce productivity, labour and production costs. At the same time, supply chains create a tremendous footprint on scarcely available resources and cause serious societal and environmental problems. Intensified pressures from governments, customers, employees, civil society organisation (CSOs) and other stakeholder groups have prompted companies to address societal and environmental impacts of their activities (Roberts 2003; Zadek 2004; Seuring and Müller 2008a, b; Björklund 2011). Taking account of issues like ethical sourcing, workers' rights, fair wages, intellectual property rights, carbon and water footprints is becoming a silent feature of discussion. This change is driven by various forces. Firstly, information flow has become faster, and therefore incidents of environmental misconduct, human rights violations or unethical business behaviour are immediately reflected in the market. This tendency is clearly visible when a striking corporate scandal occurs, as in the cases of, for example, the Volkswagen emissions scandal; the quality-faking admission from Kobe Steel (auto and airplane parts provider of Boeing, Ford, Toyota, and others); Samsung Electronics dealing with exploding Note 7 batteries and bribery charges; credit rating firm Equifax making profits from selling personal, often sensitive information to financial institutions and lenders; or recent controversies around misuse of Facebook users' data by Cambridge Analytica and potential implications for the US presidential elections in 2016. Secondly, we as consumers alter our beliefs, attitudes and buying behaviour due to societal and environmental concerns, and therefore we scrutinise companies accordingly to their reputation (Pelsmacker et al. 2006; Newholm and Shaw 2007; Castaldo et al. 2009). Thirdly, corporate reputation becomes an important factor for companies and plays a crucial role in attracting employees (both current and future) as well as investors (Maden et al. 2012; Stammer 2016).

These SCM concerns are not new and have been broadly discussed by industry, governments and researchers in the fields of SCM and business ethics (BE) from societal,

\footnotetext{
${ }^{1}$ Sedex case study derives from the author's contribution to the SATORI report "How Globalisation Is Changing Research Agendas, Activities and Assessment Procedures within Research \& Innovation. Deliverable 3.3" compiled by Sudeep Rangi (UNESCO), published in September 2015. The report is available online: http://satoriproject.eu/work_packages/legal-aspects-and-impacts-of-globalization/
} 
environmental, economic, legal, ethical and technological perspectives, which are all closely interrelated (Carter and Rogers 2008; Seuring and Müller 2008a, b; Pagell and Wu 2009; Carter and Liane Easton 2011; Ahi and Searcy 2013; Marshall et al. 2015). Yet the current focus has altered from the question of why companies should implement responsibility and sustainability into SCM activities, to how they should do so effectively. Therefore, in this article the author shifts the conceptual focus from a question of "why" to "how". Accordingly, the author's objective is to develop a theoretical account of how supply chains can be managed in a responsible and sustainable way and test this account by applying it in a case study. Companies search for solutions which decrease their negative and increase their positive societal and environmental footprints in their supply chain. Nevertheless, despite intensified efforts to ameliorate these problems, current solutions are unsatisfactory. Consequently, this study argues that new business and governance models are needed to manage supply chains in a responsible and sustainable way. Supported by the case study of Sedex, which is a collaborative platform for buyers and suppliers, this paper argues that these models should build on three types of solutions. Firstly, responsible and sustainable SCM requires innovative technological solutions. Secondly, it necessitates political solutions in the form of multistakeholder collaborative partnerships and cooperation along, as well as across, supply chains. Thirdly, ethical solutions in the form of responsibility of various tiers of supply chains are crucial, including the responsibility of organisations of companies (supra-agency). Responsible and sustainable SCM, therefore, must take a systemic approach.

The main contribution of this paper is a unique proposal for connecting research and innovation (R\&I), a multi-stakeholder approach, and a supra-agent responsibility and governance as the inevitable interdependent solutions for responsible and sustainable SCM. In particular, the SCM governance by organisations of companies (supra-agency) is analysed. Consequently, this research argues for responsible supply chain governance. The remainder of the paper is structured as follows. Section 2 discusses the methodological approach of this study. Section 3 provides a theoretical account for SCM laying the groundwork for a discussion on how supply chains can be managed in a responsible and sustainable way. Section 4 outlines the main challenges in SCM and possible solutions for responsible and sustainable supply chains that should be address. Section 5 discusses three technological, political and ethical solutions for responsible and sustainable supply chains, namely: innovation, multi-stakeholder approach, and supra-agent responsibility and governance. In section 6 , the case study of Sedex is presented to test three aforementioned solutions in practice. Lastly, section 7 concludes the research and provides further research directions.

\section{Research Methodology}

This research is funded by and derives from the results of the SATORI Project. ${ }^{2}$ The SATORI Project focuses on ethical impact assessment of research and innovation (R\&I). Part of the SATORI Project's work addresses the ethical problem of globalisation of R\&I exploring how globalisation is changing research agendas, activities and assessment procedures within R\&I. As part of this research, six topics were investigated to address specific effects of globalisation and

\footnotetext{
${ }^{2}$ The research leading to these results received funding from theEuropean Community's Seventh Framework Programme (FP7/2007-2013) under grant agreement No. 612231 (Stakeholders Acting Together On the ethical impact Assessment of Research and Innovation (SATORI)).
} 
ethical considerations. Responsible Supply Chain was one of the topics. This paper is partially derived from the SATORI Project's findings, nevertheless it provides further insight and analysis.

This paper incorporates literature review and synthesis, empirical investigations, and the development of a conceptual tool. A preliminary literature review was conducted to identify trends, challenges, ethical implications and recent developments in SCM. Furthermore, the study provides the outline of recent endeavours, policies and actions to mitigate the undesirable and unethical consequences of the SCM.

To identify potential solutions for responsible and sustainable SCM, the paper derives its findings from the literature review and the empirical studies about responsible and sustainable supply chain conducted for the purposes of the SATORI Project. Two empirical methods were used, namely a stakeholder dialogue and a case study. Studies were conducted to verify the preliminary literature review results, to determine and structure the effective conditions of responsible and sustainable supply chain.

Firstly, a stakeholder dialogue session about responsible supply chains was held in June 2015 as one of the sessions at the SATORI Project's conference titled "Policy and Legal Options for Developing Ethics Assessment for Research and Innovation Within the Context of Globalisation”. The stakeholder dialogue involved twenty participants representing industry, academia, policy makers and civil society organisations (CSOs). A stakeholder dialogue is a commonly accepted method to develop solutions acceptable to all parties, by incorporating public values and concerns into decision making (Gurzawska et al. 2017). Therefore, the session brought together stakeholders to enable discussions and gather concrete feedback on the preliminary literature review studies disseminated among the participants beforehand. The ultimate goal was to develop potential policy, legal and/or other options for responsible and sustainable supply chains. The dialogue enabled deliberation on challenges within supply chain that have arisen due to globalisation practices and proposed mechanisms to address the lacunae which exists presently. As a result, the stakeholder dialogue paired with a literature review allowed for the identification of three potential solution that participants agreed are typically effective or have a potential to enhance responsibility and sustainability in supply chains.

The second empirical method - the case-study, was conducted to test the findings of the literature review and stakeholder dialogue. This research extends the objective of identifying potential solutions by providing an empirical validation based on a case-study of Sedex, where focus was placed on specific incidents, actions, and policies. The case study employed an indepth interview with Jo Webb (Head of Stakeholder Relations at the time of the interview) and an online information exchange with Sedex employees from the departments of Stakeholder Relations and Marketing Communications. Furthermore, the content analysis of the secondary data was conducted, including Sedex documents, policies and tools provided by the organisation members as well as available online. As a specific example of responsible supply chain network organisation - Sedex, its structure and operations represent a response to SCM challenges and implementation of the proposed underlying solutions for responsible and sustainable supply chain. This research examines Sedex by applying a conceptual framework developed explicitly for the purposes of this paper.

\section{Theoretical Background}

In order to identify conditions under which supply chain can be perceived as responsible and sustainable, firstly a question of what makes supply chain responsible and sustainable needs to 
be addressed. This section provides a theoretical account for understanding and analysing responsible and sustainable SCM.

In terms of the scientific endeavours to tackle this question, a considerable body of literature examining various aspects of SCM has been produced. Carter and Jennings (2002) and Murphy and Poist (2002) were one of the first to connect supply chain issues to a broader concept of corporate social responsibility (CSR) placing environmental as well as social activities within the context of social responsibility (Carter and Liane Easton 2011). Under the CSR framework, responsibility in the supply chain falls into the conceptual discussion about the nature and, thereby, the definition of CSR. Broadly speaking CSR refers to responsibility, thereby duties and obligations or motivation and opportunities of the companies towards society (Rangi et al. 2015). There is a great number of theories and a wide array of understanding of the responsibility of a company. According to a comprehensive review of CSR definitions by Dahlsrud (Dahlsrud 2008), CSR can be characterised by five dimensions, namely environmental, social, economic, stakeholders and voluntarism (Dahlsrud 2008). Garriga and Mele (Garriga and Melé 2004) group CSR theories into instrumental, political, integrative, and ethical theories (Garriga and Melé 2004). Firstly, CSR when understood instrumentally is about a company's responsibility for wealth creation, where economic objectives are achieved through social activities (e.g. Friedman 1962). Secondly, CSR can be understood as a responsibility in the political arena related to a company's political power and relationship with society (political theories) (e.g. Matten and Crane 2005; Scherer et al. 2016; Scherer 2018). Thirdly, a company's responsibility focuses on the integration of social demands and operating according to social values (integrative theories) (e.g. Carroll 1979; Wood 1991). Finally, social responsibility can refer to ethical obligation to achieve good society, reflected in such approaches as universal rights and sustainable development. Regardless the perception of a company's responsibility nature as either economic, political, integrative or ethical, CSR concerns two aspects: the relationship between business and the larger society, and a company's activities in the area of environmental and social issues (Andersen and Skjoett-Larsen 2009). CSR refers to all company's activities and therefore also SCM as one of them.

Much of the supply chain research pertains to the CSR literature, however the last decade has seen a growing body of a standalone research on the theory and practice of sustainable supply chain management (SSCM) (Svensson 2007; Carter and Rogers 2008; Seuring and Müller 2008a, b; Carter and Liane Easton 2011; Wolf 2011; Wu and Pagell 2011). Carter and Liane Easton (2011) argue that even though previous work on supply chain in the context of CSR addresses environmental and social issues, it fails to connect SCM with the economic performance (Carter and Liane Easton 2011). Therefore, they advocate for a separation of SSCM from the CSR framework. Carter and Rogers (2008) link sustainability in the SCM context to Elkington's (1998) triple bottom line (TBL) based on the integration of social, environmental, and economic aspects of SCM (Seuring and Müller 2008a, b; Carter and Liane Easton 2011). In other words, sustainability practices help to unfold opportunities and manage economic, environmental and social risks resulting in a long-term value creation (López et al. 2007). Moreover, Carter and Rogers (2008) claim that while corporate responsibility is perceived as discretionary, the engagement in sustainability, particularly SSCM, is a requirement for any company. Nevertheless, similarly to CSR, the term 'sustainability' has been inconsistently defined and applied in the literature (Carter and Rogers 2008). A recent review of the literature on the state of sustainability and CSR in supply chains literature by Quarshie et al. (2016) found significant differences between SCM and BE fields. According to their study, while a vast amount of the SCM literature stream focuses on environmental dimensions 
of SCM using sustainability as an umbrella term; the BE literature stream is centred around social and/or ethical aspects of SCM, with a main reference to CSR (Quarshie, Salmi et al. 2016). Furthermore, while social responsibility and sustainability have been addressed in both SCM and BE research, it has been often done from a narrow perspective dealing with specific issues such as product safety, fair labour practices, modern slavery, child labour, environmental stewardship focused on climate change, carbon and water footprints or other issues that relate to socially and environmentally desirable outcomes (Ferrell et al. 2013). Most of the SCM research has focused on specific topics - and in this sense has been fragmented.

This discrepancy is also reflected in practices of companies, industry associations and governmental organisation (Rangi et al. 2015). For instance, the International Chamber of Commerce (ICC) refers to "supply chain responsibility" (also understood as responsible sourcing), as 'a voluntary commitment by companies to manage their relationships with suppliers in a responsible way' (ICC 2008). On the other hand, United Nation Global Compact (UNGC) calls for "supply chain sustainability" to "create, protect and grow long-term environmental, social and economic value for all stakeholders involved in bringing products and services to market' (UNGC 2015). While the first definition emphasises the voluntary character of companies' commitment to undertake responsible approach to supply chain (Rangi et al. 2015), the second definition focuses on management of impacts that a company may have on its stakeholders and strives for a proactive approach to incorporating good societal, environmental and governance practices into supply chains (UNGC Australia). The inconsistency in definitions and approaches could be caused by the fact that the field of SCM is relatively new, both in the context of CSR and sustainability. Overall, the varying interpretations of the terms 'CSR' and 'sustainability' make it difficult to delineate exact boundaries and linkages around them, but certainly the concepts overlap considerably (Quarshie et al. 2016). Unquestionably, both concepts are now well established in the academic research as well as in the business lexicon. One can conclude that there is a need for integration of various approaches.

This research continues to leave unresolved fundamental antecedent questions concerning the ultimate definitions of CSR and sustainability, and takes a holistic understanding of responsible and sustainable SCM, drawing from the crucial aspects of both concepts. The paper takes a comprehensive view, where responsible and sustainable SCM is about the management of material, information and capital flows, cooperation among companies along the supply chain while combining three sustainability goals i.e., economic, environmental and social goals, which are derived from customer and stakeholder requirements (Seuring and Müller 2008a, b). These goals should be taken due to the corporate social responsibly resting with companies, in the forms of responsibility for wealth creation, a responsible use of business power in the political arena, integration of social demands and acting according to ethical values (Garriga and Melé 2004). Despite differences in terminology, as well as in focus, between different researchers, there is a growing consensus around the crucial elements of responsible and sustainable SCM. Deriving from Beske et al. (2014), these elements include the equal consideration of all three dimensions of sustainability (economic, environmental and social), the cooperation of the partners in the chain (Seuring and Müller 2008a, b), strengthening long-term relationships (e.g. Sharfman et al. 2009) and legitimate requirements of the stakeholders of a supply chain, including customers, NGOs, suppliers or legal authorities (e.g. Coe et al. 2008; Johnston and Linton 2000).

From this section we have learned that responsible and sustainable SCM should consist of two elements. Firstly, it should include socially responsible SCM and SSCM. Secondly, the key elements of responsible and sustainable SCM should be taken into consideration, namely 
all sustainability dimensions (economic, environmental and social), cooperation and strong relationships between the partners of supply chain, as well as proactivity and responsiveness towards various stakeholders and their needs. These, then, are two elements of the theoretical account which define responsible and sustainable SCM and its crucial elements.

\section{SCM Challenges}

In order to specify and understand avenues for a responsible and sustainable SCM, we need to understand what challenges they should respond to. Therefore, potential solutions are determined by the challenges for both, the management of supply chains and for incorporating responsibility and sustainability into SCM.

Storey and Godsell (2006) point out that the main issue related to SCM, is the very idea of 'management' of the supply chain, and the question of who could and should be responsible for it. The formula for assigning the responsibility is a challenge, because of an unambiguous definition of the 'scope of responsibility' including the duration and severity of the impact (Van Opijnen and Oldenziel 2011). According to Amaeshi et al. (2008) a company should not bear indefinite responsibilities for the actions of the suppliers, nevertheless should strive for a positive influence on their suppliers. Except the assignment of responsibility, a successful SCM requires strategy and measuring key parts to understand and take control of the supply chain, which involves processes, people and technology (Bala 2014). In this regard, effective management of supply chains raises further questions, such as transparency of information and knowledge (Abeyratne and Monfared 2016), the formation of appropriate relationships, and the design and use of appropriate measurements (Storey and Godsell 2006).

Nevertheless, Pagell and Wu 2009 emphasise that best practices and managerial systems traditionally associated with well run supply chains may support, but also hinder sustainably and responsibility of SCM. Therefore, responsibility and sustainability goals, practices and cognitions require changes in the management style and integration into day-to-day SCM (Pagell and $\mathrm{Wu} 2009$ ). This raises two main challenges, namely a reconceptualisation of the chain to include non-traditional members such as NGOs, community members and even competitors, as well as a proactive approach of managers that understand that responsibility and sustainability are an organisational commitment (Pagell and Wu (2009). In the context of responsible and sustainable SCM challenges, Seuring and Müller (2008a, b) determine a number of challenges by dividing them between factors that are external and factors that are internal to the supply chain. The external challenges involve legal demands/regulation, customer demands, response to stakeholders, competitive advantage, environmental and social pressure groups and reputation loss. The internal factors relate to costs associated with the increasing complexities of supply chains, monitoring, communication and information exchange. Barbosa-Póvoa (2009) highlight the difficulties in establishing measures for sustainability within the sustainable supply chains; facilitation of collection, refurbishment, recycling or disposal of returned products; uncertainty and risk modelling; and trading-off the different issues in supply chain. Van Opijnen and Oldenziel (2011) discuss a level playing field related to power relations (e.g. MNCs versus SMEs or small farmers) and transparency with regard to disclosure and monitoring of sustainable practices further down the supply chain. Beske et al. (2014) identify five categories of practices, both strategic and operational, which remain a challenge for responsibility and sustainability within SCM: a strategic orientation following sustainability strategy; continuity of relationships among supply chains' partners (long-term); 
collaboration in terms of logistics and organisation; risk management in order to mitigate risks related to stakeholder pressures; pro-activity for sustainability including actively engaging stakeholders. Boström et al. (2015) capture this variety of challenges to achieve responsible and sustainable global supply chains in six comprehensive groups, namely (1) geographical distance between the consumption of commodities and their production related to complexity of the supply chain, issues with communication with suppliers, traceability and generic standards; (2) information and knowledge gaps diminishing transparency; (3) collaboration and communication along the chain; (4) compliance or implementation gaps; (5) power gaps due to the fact that responsible and sustainable supply chains require power symmetry or more equal distribution of power among actors in the chains; (6) a credibility or legitimacy gap related to unsustainable activities under the name of 'sustainability instruments'. These six challenges reflect the key elements of responsible and sustainable SCM defined in the previous section. On the one hand, they address strategic, operational and technical challenges for the arrangement of well-functioning management systems for supply chains. On the other hand, they raise a question of the nature and scope of companies' responsibility and the elements of sustainability. They focus on the dimensions of sustainability (economic, environmental and social), the cooperation of the partners in the chain, strengthening long-term relationships and legitimate requirements of the stakeholders of a supply chain.

With the focus on the establishment of responsibility and sustainability within SCM, this section does not directly contribute elements to the theoretical account, but rather defines the challenges that solutions proposed in section 5 respond to. Therefore, the next section applies a theoretical account for responsible and sustainable SCM to provide solutions that address the SCM challenges, identified in this section, from a responsibility and sustainability point of view.

\section{Solutions for Responsible and Sustainable SCM: A Proposal}

Taking into consideration the characteristics of modern supply chains (the theoretical account including the responsible SCM and SSCM, as well as the challenges for establishing responsibility and sustainability in SCM), this section identifies and discusses potential avenues for managing supply chains in a responsible and sustainable way. These solutions consist of three interdependent provisions, that is to say: innovation; multi-stakeholder approach; and supraagent responsibility and governance of supply chains. This study argues that these solutions serve as an effective response to SCM challenges discussed in the previous section and have the potential to enhance responsibility and sustainability in SCM.

\section{Innovation}

Increasingly, companies are facing disruption and change in managing their supply chains. Global competition, frequently shifting markets, rapidly changing customer requirements and new continuously emerging technologies force major changes in SCM. The dynamic and complex nature of supply chain urges companies to innovate in SCM. SCM is on the cusp of major technological transformation, which is already altering how businesses exchange and share information and assets. Traditional linear supply chains are insufficiently flexible in responding to highly dynamic conditions and to the ever-changing ecosystems (Deloitte 2017). Therefore, SCM strategies shift to support global competitiveness, new products, process and 
service innovation and introduction, in addition to, rapid market responsiveness (Shen and Norrie 1999). The next generation supply chains should then be strongly time-oriented, while still focusing on cost and quality. Furthermore, growing stakeholder pressure to realising more responsible and sustainable paths in SCM requires changes of behaviour and organisational, as well as technological, innovations (Isaksson et al. 2010). As shown by Chakrabarty and Wang (2012) high research \& development (R\&D) intensity provides a positive platform for the development and long-term sustenance of sustainability practices bringing both financial returns and a positive impact on the natural environment, society, and economy. R\&D, which is a part of innovation situated at the front end of the innovation life cycle, equips companies with technologically innovative capabilities and skills to fulfil the sustainability requirements (Chakrabarty and Wang 2012). New technologies expand and bring new forms of work and collaboration, like virtual networks (Zink and Zink 2008). According to Deloitte (2017), next generation technologies will allow for new and more advanced collaboration, that ultimately will enhance efficiency, transparency and data sharing. As the result, supply chains are managed, largely, in a digital way.

Technology, research and innovation offer the necessary solutions for efficiency, accountability and governance of supply chains. At the same time technological advances help to address and reduce negative societal and environmental consequences that a company may cause, while still maintaining economic competitiveness (Lee et al. 2006; Golicic and Smith 2013). Quickly developing technologies such as internet of things (IoT), smart sensor networks, business intelligence, smart distribution techniques, information sharing, robotics and $3 \mathrm{D}$ printing bring opportunities for more responsible and sustainable supply chains. Nevertheless, to take advantage of the possibilities created by digitisation in supply chains, the business community, government and scientists will have to utilise ICT opportunities together (Dutch Blockchain Coalition 2018a, b, c). The next subsections discuss two examples of innovative technologies, namely big data and online platforms and blockchain technology, which have a potential to revolutionise supply chains and contribute to robust responsibility and sustainability.

\section{Big Data and Online Platforms}

Big Data is increasingly becoming a vital factor and resource for companies in the innovation of products, processes, services, and business models. The definition of "big data" refers to the size or volume of the organisation's data, but also to the variety and velocity (Hazen et al. 2014). Big data is perceived as an emerging competitive area that will transform the way in which supply chains are managed and designed (Manyika et al. 2011; Cecere 2013; Waller and Fawcett 2013; Zhou et al. 2014). Companies struggle with the question how to deal with massive amounts of data, and how to leverage and apply predictive analytics (Schoenherr and Speier-Pero 2015). The widespread use of digital technologies and an increasing amount of data has led to the emergence of big data business analytics (BDBA) that enables companies to make better decisions (Muhtaroglu et al. 2013), particularly in SCM (Wamba et al. 2015).

While Big Data is still in its infancy, it already provides several promises for SCM. Big data responds to a number of challenges for responsible and sustainable SCM identified in section 4. Real-time risk management and dynamic resource optimisations (Schoenherr and SpeierPero 2015) improve the visibility, flexibility, and overall integration of global supply chains processes (Wang et al. 2016). Therefore, big data analytics could help to facilitate the geographical distance, the complexity of the supply chain and communication with suppliers 
by filling the information and knowledge gaps. This would lead to enhanced transparency and traceability supporting monitoring and auditing. Furthermore, big data analytics could enable strategic planning in terms of sourcing and supply chain network design, as well as product design and development. Such enhancements would lead to improved compliance and stakeholder relationship, since these activities are based on collaboration and communication along the chain (Wang et al. 2016). Increasingly "data" is perceived as an important driver of innovation and a significant source of value creation and competitive advantage (Tan et al. 2015). Using advanced analytics, companies can study big data to understand the business environment (Russom 2011) and then connect these insights directly into their business processes in real time. The smart collection, analysis and use of data can provide unique insights into maintenance cycles, ways of lowering costs and enabling more targeted business decisions as well as provide feedback into market trends and customer buying patterns (Wang et al. 2016). These attributes of big data respond to the key elements of responsible and sustainable SCM. Big data could ensure the realisation of economic goals, while putting attention to environmental and social objectives. At the same time, it could facilitate collaboration among supply chain actors enhancing stakeholder relationships. Big data is particularly useful when applied in the digital platforms known as platform business models. Such platforms use technology to connect people, organisations, and resources in an interactive ecosystem and exchange value (Parker et al. 2016).

Academic research into big data in SCM has been scarce (Schoenherr and Speier-Pero 2015), nevertheless practitioners and consultancy companies have already started using big data analytics to improve SCM. One example is a full-service Big Data cloud platform created by the SAP Ariba (SAP), one of the world's largest platform business models, which supports over 3.3 million companies in over 190 countries (CIO 2018). The platform uses enabling technologies and trends such as artificial intelligence (AI), IoT and blockchain technology to analyse a companies' data and enhance their operations (SAP). SAP has placed a large emphasis on "procurement with purpose". Data from commerce transacted on the platform and suppliers on the network, is used to enhance responsible and sustainable supply chains, particularly regarding corruption, child labour, slavery/forced labour, conflict minerals, human trafficking and poverty (CIO 2018). The SAP Ariba is doing so in two ways. Firstly, a supplier risk module makes risk due diligence a natural part of the procurement process (CIO 2018). The module is fed by syndicated data from more than 600,000 sources and uses continuous monitoring and machine learning techniques to analyse over 200 environmental and social factors that companies can use to profile their suppliers against (CIO 2018). Secondly, to help clients gain real-time, actionable insights into their supplier network, SAP teams up with several partners such as Made in A Free World (CIO 2018). The organisation is a supply chain risk management software provider, which built the world's first ever Slavery Footprint platform (Made in Free World).

Despite great promises of big data, there are significant challenges in its application. Firstly, Tan et al. (2015) argue that despite a variety of analytical techniques that companies can use to mine and analyse unstructured data (i.e. predictive analytics, data mining, case-based reasoning, exploratory data analysis, business intelligence, and machine learning techniques), we lack 'analytical tools and techniques to assist firms to generate useful insights from data to drive strategy or improve performance' (Tan, Zhan et al. 2015). Secondly, as emphasised by Hazen et al. (2014) 'management decisions informed by the use of these data analytic methods are only as good as the data on which they are based' (Hazen, Boone et al. 2014). Therefore, while the technological solutions might work perfectly, the data quality problem may occur in 
terms of accuracy, timeliness, consistency and completeness (Hazen, Boone et al. 2014). Since BDBA is a relatively new area, a responsible application of Big Data requires training of nextgeneration data scientists (Schoenherr and Speier-Pero 2015) and further research and testing to ensure their robustness.

\section{Blockchain Technology}

Recently, distributed computing platforms, also known as blockchain technology, are increasingly being touted as an answer to ongoing challenges in a whole range of disciplines. Blockchain is a decentralised online database that permits a master ledger of data and transactions to be accessed securely by multiple stakeholders (Pilkington 2016). Blockchain has been much in the news because of the cryptocurrency market and Bitcoins, however one of the most promising application of blockchain is for SCM. As claimed by Dickson (2016), it has a potential to 'transform the supply chain and disrupt the way we produce, market, purchase and consume our goods'. This technology can offer various opportunities to transform products, services and processes into digital supply chain networks and platforms, particularly through safer and more efficient ways to connect with business partners (Deloitte 2017). It serves as a database for recording transactions and events, which are then shared through a peer-to peer community.

Blockchain technology has a potential to address a number of responsible and sustainable SCM challenges. Blockchains could enable the tracking and tracing of products as well as components (Dutch Blockchain Coalition (a)). Therefore, it responds to the call for responsible and sustainable SCM regardless of the geographical distance and complexity of the supply chain, through improved communication with suppliers, traceability, covering the information and knowledge gaps strengthening transparency. As emphasised by Abeyratne and Monfared (2016), blockchain allows for collection, storage and management of key product information of each product throughout its life cycle. All members of the network can verify the transactions in the block (Hackius and Petersen 2017). This approach ensures more equal distribution of power among actors in the chains. Since every member of the network has access to the same data, blockchain provides a single point of truth (Tapscott and Tapscott 2016). This technology involves peer-to-peer interactions based on the digital signatures, thereby it enables communication and trust among the involved parties (Anjum et al. 2017). Therefore, blockchain improves relationships with stakeholder, firstly, among suppliers, contractors, and joint-venture partners resting on information sharing and collaborative partnerships; secondly, among customers, governments and the society thanks to reduced information and power asymmetry. Blockchain also enhances responsibility within the tiers of supply chain. It ensures the quality and safety of a product by reducing counterfeits (e.g. in the pharmacy supply chains) (Apte and Petrovsky 2016; Hackius and Petersen 2017). Blockchain serves as a tool for identifying misconduct from any part of the supply chain's tier, and reduces supply chain carbon footprints addressing the environmental dimension of responsibility and sustainability in SCM (Dutch Blockchain Coalition (a)). Blockchain provides a full audit trail of record along a supply chain thanks to real-time data and deep insights into a production process means (Beck et al. 2017). As a result, blockchain technology has a potential to enhance compliance with responsibility and sustainability requirements and objectives. Since blockchain transactions are timestamped and tamper-proof, they provide a single source of data integrity and therefore allow for greater oversight and control. One of the blockchain applications is smart contracts, which execute commercial transactions and agreements 
automatically and enforce the obligations of all parties in a contract without intermediaries (Deloitte 2016). Furthermore, blockchain could ensure credibility of responsibility and sustainability standards (e.g. Fair Trade and Organic) by verifying the integrity of the claims made by these certifications (Abeyratne and Monfared 2016). Blockchain technology can result in greater levels of performance generating economic benefits. At the same time, it is also expected to enhance environmental and social goals through improved collaboration and relationships with stakeholder.

Over recent years, there has been a proliferation of projects applying blockchain technology to strengthen SCM. One of them is the Blockchain Supply Chain Traceability Project using digital technology in the fresh and frozen tuna industries of the Western and Central Pacific region (WWF Global 2018). The objective is to improve tuna traceability to help stop illegal and unsustainable fishing practices in the Pacific Islands tuna industry (WWF Global 2018). The World Wildlife Fund (WWF) pilot project tracks fish from vessel to the supermarket, using a combination of radio-frequency identification (RFID) tags, e-tags/quick response (QR) code tags and scanning devices to collect information about the journey of a tuna at various points along the supply chain (WWF Global 2018). The information is automatically uploaded to the blockchain. Tuna industry struggles with illegal and environmentally dubious fishing practices, as well as forced labour. Blockchain technology is expected to improve traceability, compliance, flexibility and stakeholder management of tuna supply chain and enable consumers to shop ethically, legally-caught, sustainable tuna with no slave labour or oppressive conditions involved (WWF Global 2018).

Another example of the blockchain application in the SCM is a Responsible Cobalt Initiative in Congo, which has been joined by tech giants such as Apple and Samsung. The initiative aims to ensure that cobalt, one of the minerals used in electronics, come through supply chains free of rights abuse, especially child labour (Reuters 2018). The electronic sector is a highly competitive, and companies' existence and a success depends on innovations (Rangi et al. 2015). The complexity of links in the supply chain that include extraction, production and disposal, have spurred sectoral initiatives such as Ethical Trading Initiative (ETI), Conflict-free Tin Initiative or Conflict Free Sourcing Initiative. Nevertheless, Responsible Cobalt Initiative is different in this regard, because of the blockchain application. Blockchain technology is already used in the diamond industry, where gems are given a digital fingerprint, which is then tracked by blockchain (Reuters 2018). Nevertheless, tracking cobalt is far more complex since cobalt is being processed in the supply chain. Therefore, the pilot project experiments with already proven approaches from other industries, especially from the food industry, e.g. a mass balance approach used for Fairtrade certification of products like cocoa, indelible marks that survive the refining process, or bolting blockchain onto computer technology (Reuters 2018).

Despite the enthusiasm about great opportunities that the blockchain technology may generate, it also raises concerns (Yli-Huumo et al. 2016; Xu 2016; Anjum et al. 2017). According to the Dutch Blockchain Coalition, large-scale blockchain applications can only be realised if all relevant stakeholders are willing to collaborate and appropriate political, administrative, legal, economic and social conditions are in place (Dutch Blockchain Coalition (b)). These conditions are necessary to reduce risks related to the use of the technology, including regulations and the creation of markets, legal liabilities, privacy, consumer protection, conflict mediation and arbitration and contract law. Such conditions are also needed in the establishment of new roles of trusted third parties, roles of identifying and certifying parties, functioning of smart contracts, the right to erasure (former "the right to be forgotten"), and new possibilities and roles for compliance and audit functions (Dutch Blockchain Coalition (c)). As 
emphasised by the Wold Economic Forum (2018), blockchain technology is at relatively early stage; ' anchoring on blockchain without consideration of associated risks, including, among others, cost, security and the relevant industry's regulatory environment, can be detrimental.'

Therefore, even though technological advances could enhance responsibility and sustainability of SCM, issues such as conflicts, climate change, and modern slavery - are political questions and they cannot be resolved without political, social, ethical and economic solutions. Technological answers alone are unlikely to be sufficient. Ferrell et al. (Ferrell et al. 2013) argue that 'the unbalanced focus on technological innovations requires oversight by supply chain members to develop programs that inform about mutual ethical risks and to address solutions to ethical and social issues. This makes it necessary to have communication and coordination about ethical decisions throughout the supply chain' (Ferrell et al. 2013). Therefore, despite technological solutions, responsible and sustainable SCM requires the engagement of various stakeholders. The next section discusses the second potential avenue for responsible and sustainable supply chain, thereby multi-stakeholder approach.

\section{Multi-Stakeholder Approach}

Research, innovation and technology can improve efficiency and sustainability of supply chains e.g. reduce resource utilisation (empty miles) through smart logistics. Nevertheless, without the intensified coordination and cooperation between the tiers of supply chains, technological innovations cannot improve the impact on the society and environment by itself.

The main characteristic of supply chains is their multi-tier nature, engaging various stakeholders from manufacturers, intermediaries, and end users, to a host- and home country's government and local community. Increasingly, collaboration in the forms of stakeholder engagement and multi-stakeholder approaches in SCM, also known as cross-sector social partnerships (CSSPs) (Doh et al. 2010; Van Huijstee and Glasbergen 2010; Ritvala et al. 2014), is considered as the most effective way to achieve more responsible and sustainable SCM. Multi-stakeholder approaches are expected to overcome the limitations of top-down approaches toward promoting responsibility and sustainability (Vurro et al. 2009). Now we observe the proliferation of such initiatives as the Ethical Trading Initiative (ETI), an alliance of companies, trade unions and NGOs that promotes respect for workers' rights, and the Initiative to improve the Food Supply Chain, the European Commission's initiative to improve the governance of the food supply chain with regard to unfair trading practices, producer cooperation and market transparency. The engagement of various stakeholders in the discussion about responsibility and sustainability of supply chains was a response to disillusionment with previous CSR initiatives and codes of conduct. As pointed out by Utting (2002), they were designed and implemented exclusively by companies, and as a result they were ineffective and often aimed at marketing purposes rather than substantial improvements in societal and environmental performance (Utting 2002). Multi-stakeholder approaches encourage stakeholder dialogue and "social learning" (Utting 2002). The success of working towards more responsible and sustainable management of supply chains heavily depends on the involvement and contribution of other actors, such as governments, suppliers, NGOs and communities (Van Opijnen and Oldenziel 2011).

The multi-stakeholder approach is rooted in the stakeholder theory and a relational view, where companies' success depends on building and maintaining sustainable and durable relationships with the members of its stakeholder network (Tencati and Zsolnai 2009). The widely used definition by Freeman (1984) describes stakeholders as 'those groups who can 
affect or are affected by the achievement of an organisation's purpose' (Freeman 1984). The identification of stakeholder should be structured and exhaustive (Achterkamp and Vos 2008). The multi-stakeholder approach in the SCM derives from the concept of collaboration and collaborative enterprise, where companies 'seek to build long-term, mutually beneficial relationships with all stakeholders and want to produce sustainable values for their whole business ecosystem' (Tencati and Zsolnai 2008). Collaboration enhances companies' relationships with stakeholders through better coordination of the company with its suppliers, customers, or other stakeholders to jointly improve social outcomes (De Bakker and Nijhof 2002) and try to generate long-lasting "win-win" solutions (Tencati and Zsolnai 2009). Thus, the sustainability of the company depends on the sustainability of its stakeholder relationships (Tencati and Zsolnai 2009). This understanding of the multi-stakeholder approach clearly addresses responsible and sustainability challenges in terms of collaboration and communication along the chain as well as equal distribution of power among actors in the chains.

Through engaging in collaborative multi-stakeholder initiatives, companies may be better equipped to monitor and trace supply chain activity, while an individual company may not have the resources to consider the societal and environmental impacts of its activities (Clarkson 1995). Nevertheless, multi-stakeholder collaboration requires deeper relationships which might need a much longer time horizon to develop, implement and yield performance benefits and monitoring capabilities (Klassen and Vereecke 2012). The role of NGOs is crucial, as they bring 'on the ground' knowledge and experience from working with a particular group of stakeholders e.g. consumers or local communities. This knowledge provides companies with data allowing for more accurate decisions and adaptation in the dynamic SCM context. Furthermore, the engagement of various stakeholders ensures greater credibility of company operations. Multi-stakeholder collaboration encourages companies to participate in initiatives setting societal, environmental, ethical and human rights standards. Such collaboration also encourages monitoring compliance, promoting social and environmental reporting and auditing, and certifying good practice (Utting 2002). Furthermore, the interaction with various stakeholders assists in risk management, e.g. local NGOs can help companies to identify and understand the risks and opportunities in a particular country, develop plans for mitigating those risks, conduct outreach to local communities, and assess compliance with laws and responsibility and sustainability requirements. This learning process is not unilateral. Through a collaborative approach, working together and sharing information, stakeholders are better equipped to address various supply chain concerns collectively. Shared learning and joint problem-solving enables the development of best practices around SCM challenges. Each group of stakeholders brings their own unique perspective and contribution. The management of responsibility and sustainability along the supply chain is more feasible when a company considers specific stakeholder demands instead of broad societal or environmental issues (Maignan et al. 2002). High levels of cooperation and integration between partners strengthens trust and reduces or eliminates abuse of power among companies in the supply chain (Drake and Schlachter 2008). Studies of the processes by which sustainability is integrated and managed along the supply chain agree that the best performers are able to build and maintain integrated approaches toward SCM, on the basis of long-term cooperation, shared knowledge, and joint development of competence both upstream and downstream (Maignan et al. 2002, Shepherd and Gunter 2006, Strand 2009). Stakeholders are the agents that bring broad societal, environmental, ethical and human rights demands to the attention of individual company's (Maignan et al. 2002). A multi-stakeholder approach incorporates elements of responsible and sustainable SCM by allowing the equal consideration of all three dimensions of sustainability (economic, environmental and social), the cooperation of the partners in the 
chain, strengthening long-term relationships and responding to requirements of the stakeholders of a supply chain.

Multi-stakeholder approaches to SCM are co-produced by multiple stakeholders, public and private, and increasingly change the notion of governance and regulation, as well as the traditional understanding of business and politics (Hofferberth 2011).

\section{Effective Governance and Supra-Agent Responsibility}

It is increasingly recognised that responsible and sustainable SCM requires effective governance. Nevertheless, modern supply chains are characterised by the fact that they involve many distinct stakeholders operating in various countries and across many legal jurisdictions. Ideally, all agreements up and down a supply chain, and across borders, should be subjected to the same governing law provisions and have the same court jurisdiction, however in practice companies deal with a tangle of law and regulation at multiple levels (Haufler 2001). This situation raises a question of responsibility for maximal positive supply chain impacts and adverse effects such as unfair wages, disregard of occupational health and safety standards, violation of privacy, product quality and product safety or deforestation. The multi-tier nature of supply chains deepens the problem of responsibility by creating a vacuum of responsibility. The problem of "many hands" may lead to a situation when no one is responsible for either preventing and mitigating negative impacts or exercising a positive influence.

Over the past decades, a number of efforts have been made to answer these needs at national and international levels. At the national level, states have expanded the nature and scope of their legislative control and changed the nature of regulation, mostly through extending national law into extraterritorial jurisdiction in order to impose some form of corporate liability (Backer 2012). Furthermore, states have transformed their policies from corporate charity to concrete policies addressing the need to change the legal regulation of corporations (Backer 2012). At the international level the UN "Protect, Respect and Remedy" Framework for Business and Human Rights and Guiding Principles on Business and Human Rights (UN, 2008) provide the first global standard for preventing and addressing the risk of adverse impacts on human rights linked to business activity (OHCHR). This rests on three pillars: The State duty to protect against human rights abuses by third parties, the corporate responsibility to respect human rights (to act with due diligence) and greater access by victims to an effective remedy (UN, 2008). Nevertheless, these responsibilities are seen as complementary, rather than shared (Wettstein 2015). Clapham suggests that companies' responsibility to respect human rights is conceived as a moral rather than legal responsibility. Companies' responsibilities are understood as a negative responsibility "not to infringe on the rights of others", in other words "to do no harm" (Pogge 2008; Wettstein 2012). However, Wettstein (2015) argues that silent complicity, a situation that does not involve an active contribution by the corporation to a specific wrongdoing, may challenge the effectiveness of the Framework, because positive obligations are not included (Wettstein 2015). Furthermore, companies cannot be held responsible in cases 'in which they were not a causal agent, direct or indirect, of the harm in question' (Ruggie 2004). In complex supply chains the attribution of harm to specific tier of supply chain becomes increasingly difficult (Green 2012). As Louise Arbour, a former United Nations (UN) High Commissioner for Human Rights, points out 'the growing recognition that the private sector has responsibilities to respect human rights is also welcome. But means of holding States and non-States actors accountable for their actions in relation to human rights are still wanting' (Clapham 2006). 
Globalisation of markets, rapid growth of transnational corporations, and new technologies require us to rethink some of the certainties of the Westphalian age and state-dominated order to come up with new normative visions and concepts to deal with the new problems with which we are faced in a transnational world (Backer 2012). This changing state of affairs brought up the question of international governance framework that would guide and regulate the activities of companies, and therefore ensure responsibility and sustainability of supply chains. In the absence of effective national and international intergovernmental organisational regulation, nowadays we observe an expansion of "private" alternatives, such as voluntary, self-regulatory initiatives and shared governance by non-state actors where responsibility lies at the supra-agent level (Howlett 2000; Haufler 2001; Gunningham et al. 2003; Ruggie 2004; Bernstein and Cashore 2007; Haufler 2013). These initiatives are also referred by some authors as Transnational Private Regulation (TPR) (Bartley 2007; Bomhoff and Meuwese 2011; Scott et al. 2011; Cafaggi 2013). Supra-agency takes the form of 'coalitions of non-state actors which codify, monitor, and in some cases certify firms' compliance with labour, environmental, human rights, or other standards of accountability' (Bartley 2007). Regulation increasingly becomes coproduced by public and private actors and occurs on different levels (Hofferberth 2011). These private governance mechanisms involve companies, NGOs, and sometimes other actors, such as governments, academia or unions, networks of companies and industry associations, epistemic communities and technical experts to tackle societal and environmental challenges across industries and on a global scale (Utting 2002; Gilbert and Rasche 2007; Büthe 2010; Mena and Palazzo 2012). There is a variety of models engaging businesses, associations of companies and NGOs, sometimes in hybrid form and often including governmental actors (Scott et al. 2011). These initiatives in the majority embody the multi-stakeholder approach (as discussed in the previous section) creating multi-stakeholder initiatives (MSIs). They reflect the idea that it is possible to regulate behaviour without doing so (Bomhoff and Meuwese 2011), thereby direct intervention and enforcement are replaced with 'allegedly lighter demands on economic actors to institutionalise processes' (Jordana and Levi-Faur 2004). Although, companies adopt TPRs voluntary, these regulations may be supported with a variety of formal and informal enforcement mechanisms, such as codes of conduct (Haufler 2001). Hutter (2006) identifies two main types of non-state actor regulations, either by the economic actors, or civic actors. Three main sources of regulation in the economic sector include: (1) industry or trade organisations; (2) companies themselves; and (3) those whose business is selling regulatory and risk management advice or cover to companies (consultancies); while the civic sector consists of NGOs and standards organisations (Hutter 2006).

In terms of enhancing supply chain responsibility and sustainability, non-state actor regimes offer a number of advantages addressing SCM challenges. Non-stake actors regimes may have an advantage in information gathering, hence collation and provision of information about policy issues and problem areas (Hood et al. 2001; Hutter 2006). Therefore, they address the problem of complexity of the supply chain, communication with suppliers and traceability, as well as information and knowledge gaps diminishing transparency. Hutter (2006) draws on Hood et al.'s (2001) work on risk regulation regimes, and argues that economic non-state regulators may have higher level of expertise and technical know-how, e.g. compliance officers may be better trained than the state inspectors (Hutter 2006). Moreover, compared to the public sector, businesses have higher level of financial capacity which impacts levels of expert knowledge and training (Hutter 2006). Nevertheless, there is a risk that companies may be reluctant to share information due to competition and risk of revealing business secrets. The majority of non-state initiatives use innovative technologies to improve information and data 
sharing, for instance through networks of online platforms. Combining non-state actors initiatives with technological advances, such as big data analysis and blockchain, enables real-time monitoring and decision-making ensuring improved compliance and implementation. Regarding compliance and implementation of responsible and sustainable SCM requirements, non-state regimes have a triple role to play. Firstly, they can serve as standard settings processes aimed at setting goals through standards and targets, particularly because non-state actors regulation is more flexible and sensitive to the market and technological innovation than traditional state regulation (Hutter 2006). Secondly non-state actor regimes could play a significant role in behaviour modification of companies and individuals e.g. deterrence or mixed enforcement (Hood et al. 2001). A positive motivation comes from the idea of a "race to the top" and becoming a leader in the sector. Since non-state actors regimes are composed of various organisations, control emerges from both cooperation and competition (Scott et al. 2011). As emphasised by Scott and his colleagues (Scott et al. 2011) 'these networks stimulate mutual control the competition for members or, more broadly, regulatees can increase the standards to the extent that information is adequate to support the making of choices. The use of public oversight and procedural rules is one among the many potential strategies that TPR can use to increase accountability without reducing effectiveness' (Scott et al. 2011). Selfregulation has the potential to generate compliance through so-called "regulation-byinformation", where the compliance of one member is monitored by another member. As a result, the network creates an informal feedback and sanctions mechanisms. Lastly, non-state actor regimes are to a great extent risk regulation regimes, that Hood et al. (2001) define as 'the complex of institutional geography, rules, practices, and animating ideas that are associated with the regulation of a particular risk or hazard' (Hood, Rothstein et al. 2001). Nevertheless, one of the crucial concerns is a potential lack of enforcement, which is related to the question of the effectiveness of collective actions ensuring that all companies participate and eliminate 'free riders' (Brunsson and Jacobsson 2000).

Non-state actors regimes question the traditional legal order of norms creation and their enforcement. They are part of a broader discussion about better regulation (Bomhoff and Meuwese 2011) and good governance. These new governance models reflect the shift from hierarchical to heterarchical governance and recognise the need to reconceptualise the bases of legitimacy for such regimes at both national and supranational level (Teubner 1997; Scott et al. 2011). Curtin and Senden (2011) investigate an accountability perspective of TPRs and propose two distinct alternatives for the top down approach to the control and accountability of TPRs. Firstly, the advantage of "choice" of regulators who regulates them and of consumers which self-regulatory regimes protect (Curtin and Senden 2011). Secondly, networks of mutuality, rooted in the interdependence of actors, not only between regulatees but also between regulators and those protected by the regime (Scott et al. 2011). Non-state actors regimes have a potential to improve collaboration and relationships with stakeholder, and become a realisation of two key elements of responsible and sustainable SCM - meaningful multi-stakeholder relations and stakeholder engagement where preferences of all stakeholders and the varieties of perspectives are addressed (Scott 2010). As a consequence such an approach may lead to novel forms of democratic governance, at transnational level, which are not tied to national electoral politics (Scott et al. 2011). These changes into outsourcing and privatisation of public management functions reflect changes in broader patters of social control (Cohen 1985; Hutter 2001).

These regimes can serve as powerful governance mechanisms. Nevertheless, they are unlikely to govern effectively if they are based exclusively on companies' strategic interests 
for compliance (Meidinger 2017). While the responsibility of companies in the form of accountability and legal liability is broadly discussed in the literature as well as among practitioners, non-state actor regimes are not accountable to states. As a result, organisations leading non-state actor systems cannot be held responsible either for its own misconduct or misconduct of its members. In order to be effective they must establish "political legitimacy" uniting companies, NGOs, and other SCM stakeholder into a community that accepts 'shared rules as appropriate and justified' (Bernstein and Cashore 2007).

\section{Summary of the Proposed Solutions}

Section 5 identifies three potential solutions for challenges to responsible and sustainable SCM taking into consideration the theoretical account for responsible and sustainable SCM. This consists of the concepts of CSR and SSCM with three key elements of responsible and sustainable SCM, namely the equal consideration of all three dimensions of sustainability (economic, environmental and social), the cooperation of the partners in the chain, strengthening long-term relationships and legitimate requirements of the stakeholders of a supply chain. Moreover, the potential avenues are determined by the challenges for responsible and sustainable SCM. Firstly, innovative technologies, such as big data and blockchain, offer solutions for the enhancement of positive and reduction of negative societal and environmental consequences that a company may cause, while still maintaining economic competitiveness. Through digitalisation of supply chains they enable communication and collaboration among supply chains stakeholders leading to deeper relationships. Secondly, a multi-stakeholder approach ensures inclusion of various supply chains stakeholders and their legitimate requirements. Thirdly, non-state actor regimes provide new governance models for more responsible and sustainable SCM. These solutions address the claim, that companies should be responsible for issues of public concern not only within their company boundaries, but also along the complex and dispersed supply chains (Scherer 2018). Since companies' responsibility may have a different nature, the solutions address this diversity. Innovative technologies serve as a technological instrument enabling realisation of responsibility and sustainability within SCM. Multi-stakeholder approach has a political character, focusing on a company's political power and relationship with society. Supra-agent responsibility and effective governance responds to the call for the ethical responsibility of companies and building a good society.

This paper argues that there is a potential interplay between the technological, political and ethical solutions. Innovative solutions, such as big data and blockchain, could be used to facilitate multi-stakeholder initiatives and non-state actor regimes by providing a forum for the involvement and collaboration of various supply chain actors. Many non-state actor initiatives use innovative technologies to support information and data sharing among various stakeholders, particularly through multi-stakeholder digital platforms connecting people, organisations, and resources. This approach enhances compliance and implementation through mutual control. Digital platforms applied in the context of multi-stakeholder non-governmental initiatives, enable transparency leading to cooperation and integration between partners strengthens trust and reduce or eliminate abuse of power. At the same time, technological innovations require oversight by multiple supply chain stakeholders to enable communication and coordination about ethical decisions throughout the supply chain (Ferrell et al. 2013). Moreover, non-state actor governance models should be based on multi-stakeholder collaboration and mutual control to ensure a credibility and legitimacy of the initiative. Lastly, a combination of technological, political and ethical solutions involving the development of 
sound, multi-stakeholder business and governance models supported by innovative technologies, have a potential to address a variety of challenges in SCM from a responsibility and sustainability point of view.

\section{Case Study: Sedex}

To illustrate the application and effectiveness of solutions for responsible and sustainable SCM (innovation, multi-stakeholder approach, and effective governance and supra-agency), this section presents the case study of Sedex. Formed in 2004, Sedex (The Supplier Ethical Data Exchange) is a not for profit membership organisation working with buyers and suppliers worldwide to deliver improvements in responsible and ethical business practices in global supply chains (Sedex Global (a)). Sedex is the world's largest collaborative platform providing leading-edge services for managing and sharing ethical supply chain data, which multinational companies use to understand, monitor and manage supply chains risks and improve standards (Sedex (a)). Sedex brings together more than 38,000 companies (buyers, suppliers and audit firms) from across 28 sectors (e.g. chemicals, engineering, IT, telecom \& electrical, drugs and pharmaceutical products) in over 150 countries (Sedex (b)).

\section{Innovation}

Sedex offers a secure, online database that allows members to store, share and report on information in four key areas: labour standards, health \& safety, the environment, and business ethics (Sedex (a)). Sedex has three groups of members that reflect the different levels of functionality available in the Sedex system - Buyer membership, Buyer/Supplier membership and Supplier membership (Sedex (c)). Sedex's electronic system collects and analyses information on ethical and responsible business practices in the supply chains (Sedex (d)). Moreover, Sedex offers a variety of reporting tools that enable buyers to keep track of their suppliers' performance, in addition to an advanced Risk Assessment Tool (Sedex (d)). Suppliers, who participate in the Sedex network, can share information with multiple customers in an efficient and cost-effective way (Sedex (d)). By enabling sharing the same data with many customers, Sedex helps reduce the need for multiple audits. As a result, the Sedex online system may enable greater traceability, transparency and flexibility of supply chains with improved stakeholder relations and communication. With regard to the main ethical risks in the supply chain, Sedex notes that the key risks can be very varied. Common noncompliances in social audits include health and safety issues as well as non-compliance related to wages and working. Other issues such as discrimination, bullying and bonded labour can be harder to tackle, because they are not always as easy to find through the audit process. Data from a briefing by Sedex shows that fire safety non-compliances make up a $1 / 3$ of all health and safety non-compliances globally (Sedex (g)). This level of data mining helps companies understand global trends and scale of issues. Sedex works to ease the burden on suppliers facing multiple audits, questionnaires and certifications; but at the same time, it drives improvements in the ethical performance of global supply chains (Sedex (a)). At the time the case study was conducted, Sedex was working on increasing the capacity within its technology team to help support the quality and timings of delivery. In addition, Sedex has been researching an online extranet that will allow members to collaborate and continue discussions more efficiently (Sedex 2017). 


\section{Multi-Stakeholder Approach}

Sedex aims to drive collaboration, increase transparency and build the capacity that is needed to raise standards across all tiers of the supply chain (Rangi et al. 2015). The Sedex Stakeholder Forum (SSF) (previously known as the Associate Auditor Groups (AAG)) brings together leaders from across the ethical trade and responsible sourcing industry to discuss the challenges they face and solve them collaboratively (Sedex 2017). SSF's mission is to drive convergence and best practice in auditing (Sedex 2017). The Forum is based on a participation of multiple stakeholders (brands, retailers, suppliers, NGOs, industry experts, associations and monitoring firms) significantly involved in ethical trade auditing (Sedex 2017). The SSF is composed of a collection of dynamic working groups (Sedex 2017). The SSF working groups cooperate to develop responsible sourcing content and methodologies solutions that are "fit for purpose" (Sedex 2017). These solutions are designed for all users and stakeholders (Sedex members, non-members, workers and their communities) with the aim of improving business performance and workers' lives (Sedex 2017). Moreover, SSF provides guidance and direction to Sedex staff. They helping develop the products and services to manage responsible sourcing in the supply chains (Sedex 2017). Through SSF, Sedex seeks to engage a more global audience to help develop and review effective responsible sourcing solutions (Sedex 2017). The SSF wants to be seen as inclusive, global and interactive.

\section{Effective Governance and Supra-Agency}

Sedex is not a standard setting body; it does not have a code of conduct and does not provide certification. Sedex's role is rather to enable companies to effectively share and manage supply chain information, with the aim of driving continuous improvement (Sedex (a)). Nevertheless, Sedex advocates for applying Ethical Trading Initiative (ETI) provisions in two areas: labour $\&$ health and safety standards, and additionally environmental standards and business ethics (Sedex $(\mathrm{g})$ ). Sedex is code neutral; therefore, it does not require prospective members to adhere to specific criteria in order to become members. Sedex membership is about showing the commitment to drive improvements in a company's supply chain. Sedex allows companies to decide themselves how they want to proceed and assists companies in this process by providing them with a number of tools to facilitate the assessment. The assessment consists of six key steps leading to greater traceability, transparency, flexibility, legal compliance and stakeholder management, namely:

1. Supply chain mapping - Sedex helps companies to understand who their suppliers are, allowing them to map their suppliers down to multiple tiers.

2. Sedex on-line member only Self-Assessment Questionnaire (SAQ) - Through the questionnaire, Sedex asks members common questions regarding internationally accepted Labour Standards, Health \& Safety, The Environment and Business Ethics requirements. Members also provide input through addressing key indicators of risk and maturity in terms of managing social, governance and environmental issues. Sedex is a cross-sector/ multi-sector organisation, therefore while there is only one SAQ, depending on the suppliers profile the questionnaire filters questions that are relevant for that specific profile. At the time the case study was conducted, Sedex was working on introducing a new modular functionality to provide greater specification for certain customers or sectors. 
3. The Risk Assessment tool - Sedex has developed this tool in partnership with global risk experts Maplecroft. The tool analyses hundreds of indices and factors including human rights violations, political risk, corruption risks, and child labour alongside management proficiency and ability to mitigate risk of the individual site (Sedex (e)). The risk assessment is especially important for large companies with complex supply chains, because it can help them to understand where to prioritise their focus.

4. Audit (assessment) - The Sedex Stakeholder Forum developed the Sedex Members Ethical Trade Audit (SMETA), ${ }^{3}$ as a response to member demand for an ethical audit report format that could be more easily shared (Sedex (f)). SMETA aims to reduce the duplication of effort in ethical trade auditing, thus benefitting retailers, consumer brands, and their suppliers (Sedex (f)). According to Sedex, SMETA is 'not a code of conduct, a new methodology, or a certification process' (Sedex (f)). It is an audit procedure reflecting the compilation of good practice in ethical audit techniques (Sedex (f)). Around 10,000 audits are uploaded to the Sedex platform per year. When Sedex first launched the SMETA methodology, $90 \%$ of the audits uploaded onto the platform were based on company codes for audits whereas now $90 \%$ of the audits are performed against SMETA, demonstrating the success of the initiative. SMETA is now one of the most used audit methods worldwide. According to Sedex, 'a part of its success is that we included audit companies, brands, retailers and suppliers in its development.' SMETA consists of three elements: (1) a common corrective action plan format; (2) best practice guidance on conducting ethical trade audits; (3) a common audit report format (Sedex (i)).

5. Reporting - According to Sedex, improving awareness of a company about its supply chain can help to mitigate risk and protect its reputation. In order to enhance a company's supply chain visibility, Sedex offers in-depth, analytical reports that highlight trends, alerts a company to potential risks and help it to prioritise its resources. The huge amount of data stored by Sedex offers not only the ability to address risks but also provides examples of good practices that can inspire and guide change.

6. Capacity building - Sedex offers various capacity building tools, such as the Sedex Supplier Workbook. The workbook is a free, publicly available document offering practical guidance to help suppliers across the world to understand what 'good practice' looks like when working towards the Ethical Trading Initiative (ETI) and other Code requirements. The Workbook also offers advice on how suppliers can reach these requirements. Therefore, Sedex aims to build capacity at the bottom of the extended supply chain.

The SMETA methodology allows the auditor to raise issues regarding non-compliance against both the ETI base code (a measurable version of ILO conventions) and local laws. The first thing is to understand where issues exist against local law versus international frameworks. The next step involves working with a supplier to address and meet the minimum legal standards. However, if a supplier does this already, it can be challenging to move them to aim for an aspirational, higher level standard. Nevertheless, different approaches exist that companies can use. First, it is the purchasing power based on a customer requirement. Secondly, it is about demonstrating the business benefit to the supplier addressing them. Furthermore, cooperation and working with others can bring about great change. Sedex is an example of an organisation in which companies

\footnotetext{
${ }^{3}$ Note: The case study was conducted between May and August 2015. The latest version of SMETA was launched in April 2017, with an implementation date of June 1, 2017.
} 
work together on the same aligned framework. The collective effect of a number of companies asking for the same information, may significantly influence the behaviour of an individual company. Nevertheless, according to Sedex, there is a strong need for standardisation around international frameworks. Different legislation and standards in different countries only fragment the issue for the supply chain and can make it more confusing for suppliers. This fragmentation also reduces the willingness of companies and other actors to respond to lots of different standards. Regarding the effectiveness of the current legal framework of corporate responsibility, in the opinion of Sedex, there are a lot of companies and organisations that would say voluntary standards are effective instruments. Some larger companies are in favour of legislation, because they feel it will level the playing field. However, as emphasised by Sedex, there are clever ways of looking at how legislation works. For instance, there has been quite a lot of debate within the legal profession about the modern slavery bill that was launched in the UK. This discussion focuses on the effectiveness of a disclosure-based rule versus strengthening of existing legislation to expand it to require reporting to cover human rights in the supply chain. The interviewee emphasised that this is a question of the effectiveness of voluntary standards. Legislation has a role to play in levelling the field, however, the additional administration burden placed on the supply chains, and particularly SMEs, should be taken into account. The crucial point is that legislation should be enforced. Many of the supply chain risks are addressed in legislation, however, the legislation is not enforced. There is a strong need of a balance between appropriate legislation combined with effective enforcement. As noted by Sedex, a cross-sector approach to responsible and sustainable supply chain management should be based on collaboration. Furthermore, such an approach should not try to "reinvent the wheel", but look at different legislation, initiatives, mechanisms and standards that already exist. Supply chain policies should be grounded in implementation, because a policy has to be implemented in order to succeed.

\section{Conclusions}

This study provides an investigation into potential avenues for responsible and sustainable supply chain management (SCM) to extend the domain of ethical decision-making and provide a theoretical account to facilitate future research in this area. To identify the solutions for responsible and sustainable SCM, this study integrates current knowledge on supply chain management $(\mathrm{SCM})$ with resent theoretical and empirical developments in the field. The theoretical account consists of two elements. Firstly, it involves a notion of responsible SCM that is built up out of the concepts of 'responsible supply chain management' and 'sustainable supply chain management'. Secondly, it requires key elements of responsible and sustainable SCM, namely the equal consideration of all three dimensions of sustainability (economic, environmental and social), the cooperation of the partners in the chain, strengthening long-term relationships and legitimate requirements of the stakeholders of a supply chain, including customers, NGOs, suppliers or legal authorities. The theoretical account combined with the stakeholder dialogue allowed the identification of three solutions for challenges to responsible and sustainable SCM that companies face in practice. Firstly, to enhance responsibility and sustainability, supply chains stakeholders should use innovative organisational and technological solutions that offer greater monitoring and assessment opportunities, efficiency, and communication between tiers of supply chain. The paper provides two examples of technologies that have a potential to revolutionise SCM, namely big data analysis and blockchain technology. Secondly, supply chains should be managed in a 
collaboration of multiple stakeholders built on trust and mutual learning. Thirdly, this research argues for new SCM business and governance models. These models should be based on shared responsibility and collaboration of multiple supply chain stakeholders supported by innovative technologies. Therefore, this paper offers a unique normative proposal for connecting technological, political and ethical solutions (innovation, a multi-stakeholder approach, a supra-agent responsibility and governance) as the inevitable interdependent solutions for responsible and sustainable SCM. This article underlines the need for research that reflects the interconnected nature of the economic, societal, environmental, and ethical and human rights dimensions of SCM. The case study of Sedex shows how non-state actors governance models may effectively address SCM challenges and ensure SCM responsibility and sustainability. Sedex enhances responsibility and sustainability of supply chains through applying three solutions identified in this paper. Sedex invests in innovative technological solutions helping to share and analyse supply chain data; it brings together multiple stakeholders to develop Sedex functionalities; and it serves as a governance platform encouraging a positive behaviour change among its members.

Acknowledgments The research leading to these results received funding from the European Community's Seventh Framework Programme (FP7/2007-2013) under grant agreement No. 612231 (SATORI).

\section{Compliance with Ethical Standards}

Conflict of Interest The author declares that she has no conflict of interest.

Open Access This article is distributed under the terms of the Creative Commons Attribution 4.0 International License (http://creativecommons.org/licenses/by/4.0/), which permits unrestricted use, distribution, and reproduction in any medium, provided you give appropriate credit to the original author(s) and the source, provide a link to the Creative Commons license, and indicate if changes were made.

\section{References}

Abeyratne, S. A., \& Monfared, R. P. (2016). Blockchain ready manufacturing supply chain using distributed ledger.

Achterkamp, M.C., and J.F. Vos. 2008. Investigating the use of the stakeholder notion in project management literature, a meta-analysis. International Journal of Project Management 26 (7): 749-757.

Ahi, P., and C. Searcy. 2013. A comparative literature analysis of definitions for green and sustainable supply chain management. Journal of Cleaner Production 52: 329-341.

Amaeshi, K.M., et al. 2008. Corporate social responsibility in supply chains of global brands: A boundaryless responsibility? Clarifications, exceptions and implications. Journal of Business Ethics 81 (1): 223-234.

Andersen, M., and T. Skjoett-Larsen. 2009. Corporate social responsibility in global supply chains. Supply chain management: an international journal 14 (2): 75-86.

Anjum, A., M. Sporny, and A. Sill. 2017. Blockchain standards for compliance and trust. IEEE Cloud Computing 4 (4): 84-90.

Apte, S., and N. Petrovsky. 2016. Will blockchain technology revolutionize excipient supply chain management? Journal of Excipients and Food Chemicals 7 (3): 910.

Backer, L.C. 2012. From institutional misalignments to socially sustainable governance: The guiding principles for the implementation of the United Nations protect, respect and remedy and the construction of intersystemic global governance. Pac. McGeorge Global Bus. \& Dev. LJ 25: 69.

Bala, K. 2014. Supply chain management: Some issues and challenges-a review. International Journal of Current Engineering and Technology 4 (2): 946-953. 
Barbosa-Póvoa, A. P. (2009). Sustainable supply chains: Key challenges. In Computer aided chemical engineering (Vol. 27, pp. 127-132). Elsevier.

Bartley, T. 2007. Institutional emergence in an era of globalization: The rise of transnational private regulation of labor and environmental conditions. American Journal of Sociology 113 (2): 297-351.

Beck, R., Avital, M., Rossi, M., \& Thatcher, J. B. (2017). Blockchain technology in business and information systems research.

Bernstein, S., and B. Cashore. 2007. Can non-state global governance be legitimate? An analytical framework. Regulation \& Governance 1 (4): 347-371.

Beske, P., A. Land, and S. Seuring. 2014. Sustainable supply chain management practices and dynamic capabilities in the food industry: A critical analysis of the literature. International Journal of Production Economics 152: 131-143.

Besley, T., and M. Ghatak. 2007. Retailing public goods: The economics of corporate social responsibility. Journal of Public Economics 91 (9): 1645-1663.

Björklund, M. 2011. Influence from the business environment on environmental purchasing-Drivers and hinders of purchasing green transportation services. Journal of Purchasing and Supply Management 17 (1): 11-22.

Bomhoff, J., and A. Meuwese. 2011. The meta-regulation of transnational private regulation. Journal of Law and Society 38 (1): 138-162.

Boström, M., A.M. Jönsson, S. Lockie, A.P. Mol, and P. Oosterveer. 2015. Sustainable and responsible supply chain governance: Challenges and opportunities. Journal of Cleaner Production 107: 1-7.

Brunsson, N., and B. Jacobsson. 2000. A world of standards. Oxford University Press.

Büthe, T. 2010. Global private politics: A research agenda. Business and Politics 12 (3): 1-24.

Cafaggi, F. 2013. New foundations of transnational private regulation. Law and technology, 77-143. Pisa University Press.

Carlson, L.A., and V. Bitsch. 2018. Social sustainability in the ready-made-garment sector in Bangladesh: An institutional approach to supply chains. International Food and Agribusiness Management Review 21 (2): 269-292.

Carroll, A.B. 1979. A three-dimensional conceptual model of corporate performance. Academy of Management Review 4 (4): 497-505.

Carroll, A.B. 1991. The pyramid of corporate social responsibility: Toward the moral management of organizational stakeholders. Business Horizons 34 (4): 39-48.

Carter, C.R., and M.M. Jennings. 2002. Logistics social responsibility: An integrative framework. Journal of Business Logistics 23 (1): 145-180.

Carter, C.R., and P. Liane Easton. 2011. Sustainable supply chain management: Evolution and future directions. International journal of physical distribution \& logistics management 41 (1): 46-62.

Carter, C.R., and D.S. Rogers. 2008. A framework of sustainable supply chain management: Moving toward new theory. International journal of physical distribution \& logistics management 38 (5): 360-387.

Castaldo, S., et al. 2009. The missing link between corporate social responsibility and consumer trust: The case of fair trade products. Journal of Business Ethics 84 (1): 1-15.

Cecere, L. 2013. Big data handbook: How to unleash the big data opportunity. Maryland: Supply Chain Insight LLC.

Chakrabarty, S., and L. Wang. 2012. The long-term sustenance of sustainability practices in MNCs: A dynamic capabilities perspective of the role of R\&D and internationalization. Journal of Business Ethics 110 (2): 205217.

Chiang, C.-Y., et al. 2012. An empirical investigation of the impact of strategic sourcing and flexibility on firm's supply chain agility. International Journal of Operations \& Production Management 32 (1): 49-78.

CIO (2018). "SAP Ariba's platform strategy" Nicholas D. Evans for CIO. Available online: https://www.cio. com/article/3269294/it-strategy/sap-ariba-s-platform-strategy.html (Accessed: 15 May 2018).

Clapham, A. 2006. Human rights obligations of non-state actors. Oxford: OUP.

Clarkson, M.E. 1995. A stakeholder framework for analyzing and evaluating corporate social performance. Academy of Management Review 20 (1): 92-117.

Coe, N.M., P. Dicken, and M. Hess. 2008. Global production networks: Realizing the potential. Journal of Economic Geography 8 (3): 271-295.

Cohen, S. 1985. Visions of social control: Crime, punishment and classification. Polity Press Cambridge.

Crane, A., et al. 2014. Contesting the value of "creating shared value". California Management Review 56 (2): $130-153$.

Curtin, D., and L. Senden. 2011. Public accountability of transnational private regulation: Chimera or reality? Journal of Law and Society 38 (1): 163-188.

Dahlsrud, A. 2008. How corporate social responsibility is defined: An analysis of 37 definitions. Corporate Social Responsibility and Environmental Management 15 (1): 1-13. 
De Bakker, F., and A. Nijhof. 2002. Responsible chain management: A capability assessment framework. Business Strategy and the Environment 11 (1): 63-75.

Deloitte (2012). "Mitigating compliance risk implications for global supply chains". Available online: https:/www2.deloitte.com/content/dam/Deloitte/us/Documents/consumer-business/us-cp-supply-chain-riskcompliance.pdf (Accessed: 3 May 2018).

Deloitte (2016). "Blockchain technology - The benefits of smart contracts". Available online: https://www2. deloitte.com/nl/nl/pages/financial-services/articles/3-blockchain-the-benefits-of-smart-contracts.html (Accessed: 15 May 2018).

Deloitte (2017). "When two chains combine. Supply chain meets blockchain”. Available online: https://www2. deloitte.com/nl/nl/pages/risk/articles/supply-chain-meets-blockchain.html (Accessed: 15 May 2018).

Dickson, B. (2016). Blockchain has the potential to revolutionize the supply chain. Available online: https://techcrunch.com/2016/11/24/blockchain-has-the-potential-to-revolutionize-the-supplychain/?guccounter=1\&guce_referrer_us=aHR0cHM6Ly93d3cuZ29vZ2x1LmNvbS8\&guce_referrer_cs= cY5wdHJAIWjImheWEpiDŌw (Accessed: 10 February 2019).

DIHR (Danish Institute for Human Rights (2006). "Human rights compliance assessment (HRCA) quick check". Available online: https://hrca2.humanrightsbusiness.org/docs/file/hrca\%20quick\%20check_english.pdf (Accessed: 3 May 2018).

Doh, J., et al. 2010. Ahoy there! Toward greater congruence and synergy between international business and business ethics theory and research. Business Ethics Quarterly 20 (3): 481-502.

Drake, M.J., and J.T. Schlachter. 2008. A virtue-ethics analysis of supply chain collaboration. Journal of Business Ethics 82 (4): 851-864.

Dutch Blockchain Coalition (2018a). "The Netherlands presents first national blockchain research agenda". Available online: https:/www.dutchdigitaldelta.nl/en/blockchain/nederland-presenteert-eerste-nationaleblockchain-onderzoeksagenda (Accessed: 15 May 2018).

Dutch Blockchain Coalition (2018b). "Summary Dutch Blockchain research agenda". Available online: https:/www.dutchdigitaldelta.nl/uploads/180405-Onderzoeksagenda-blockchain-one-pager.pdf (Accessed: 15 May 2018).

Dutch Blockchain Coalition (2018c). "Blockchain: Actielijn 2 - Conditions". Available online: https://www. dutchdigitaldelta.nl/en/blockchain/actielijn-2 (Accessed 15 June 2018).

Elkington, J. 1998. Partnerships from cannibals with forks: The triple bottom line of 21 st-century business. Environmental Quality Management 8 (1): 37-51.

Eng, T.-Y. 2006. Mobile supply chain management: Challenges for implementation. Technovation 26 (5-6): 682686.

European Commission, initiative to improve the food supply chain (2018)

Commission initiative to improve the governance of the food supply chain with regard to unfair trading practices, one rule regarding producer cooperation and market transparency. https://ec.europa.eu/info/law/betterregulation/initiatives/ares-2017-3735471_en\#initiative-details (Accessed: 10 January 2018).

European Commission, Single market for Green products. Available online: http://ec.europa. eu/environment/eussd/smgp/facts_and_figures_en.htm (Accessed: 8 January 2018).

Ferrell, O., et al. 2013. A framework for understanding ethical supply chain decision making. Journal of Marketing Channels 20 (3-4): 260-287.

Freeman, E.R. 1984. Strategic management: A stakeholder approach. Vol. 46. Boston, MA: Pitman.

Freeman, R.E. 2010. Strategic management: A stakeholder approach. Cambridge university press.

Friedman, M. 1962. Capitalism and freedom: With the assistance of rose D. Friedman. University of Chicago Press.

Garriga, E., and D. Melé. 2004. Corporate social responsibility theories: Mapping the territory. Journal of Business Ethics 53 (1-2): 51-71.

Gerwin, D. 1993. Manufacturing flexibility: A strategic perspective. Management Science 39 (4): 395-410.

Gilbert, D.U., and A. Rasche. 2007. Discourse ethics and social accountability: The ethics of SA 8000. Business Ethics Quarterly 17 (2): 187-216.

Golicic, S.L., and C.D. Smith. 2013. A meta-analysis of environmentally sustainable supply chain management practices and firm performance. Journal of Supply Chain Management 49 (2): 78-95.

Green, M. (2012). Institutional responsibility for moral problems. Global Responsibilities, Routledge: 139-156.

Gunningham, N., et al. 2003. Shades of green: Business, regulation, and environment. Stanford University Press.

Gurzawska, A., et al. 2017. Implementation of responsible research and innovation (RRI) practices in industry: Providing the right incentives. Sustainability 9 (10): 1759.

Hackius, N., \& Petersen, M. (2017). Blockchain in logistics and supply chain: Trick or treat? In Proceedings of the Hamburg international conference of logistics (HICL) (pp. 3-18). epubli.

Hart, S.L. 1995. A natural-resource-based view of the firm. Academy of Management Review 20 (4): 986-1014. 
Haufler, V. 2001. A public role for the private sector. Washington, DC: Carnegie Endowment for International Peace.

Haufler, V. 2013. A public role for the private sector: Industry self-regulation in a global economy. Carnegie Endowment.

Hazen, B.T., et al. 2014. Data quality for data science, predictive analytics, and big data in supply chain management: An introduction to the problem and suggestions for research and applications. International Journal of Production Economics 154: 72-80.

Hofferberth, M. 2011. The binding dynamics of non-binding governance arrangements. The voluntary principles on security and human rights and the cases of BP and Chevron. Business and Politics 13 (4): 1-30.

Hood, C., et al. 2001. The government of risk: Understanding risk regulation regimes. Oxford: OUP.

Howlett, M. 2000. Managing the "hollow state": Procedural policy instruments and modern governance. Canadian Public Administration 43 (4): 412-431.

Hutter, B.M. 2001. Regulation and risk: Occupational health and safety on the railways. Oxford University Press on Demand.

Hutter, B.M. 2006. The role of non-state actors in regulation, Centre for Analysis of risk and regulation. London: School of Economics and Political Science.

ICC (2008). "ICC guide to responsible sourcing integrating social and environmental considerations into the supply chain." Available online: https://www.icc.fi/wp-content/uploads/ResponsibleSourcing-Brochurefinal.pdf (Accessed: 10 January 2018).

Isaksson, R., et al. 2010. Detecting supply chain innovation potential for sustainable development. Journal of Business Ethics 97 (3): 425-442.

Jia, F., et al. 2018. Sustainable supply chain management in developing countries: An analysis of the literature. Journal of Cleaner Production 189: 263-278.

Johnston, D.A., and J.D. Linton. 2000. Social networks and the implementation of environmental technology. IEEE Transactions on Engineering Management 47 (4): 465-477.

Jordana, J., and D. Levi-Faur. 2004. The politics of regulation: Institutions and regulatory reforms for the age of governance. Edward Elgar Publishing.

Klassen, R.D., and A. Vereecke. 2012. Social issues in supply chains: Capabilities link responsibility, risk (opportunity), and performance. International Journal of Production Economics 140 (1): 103-115.

Lau, R.S. 1996. Strategic flexibility: A new reality for world-class manufacturing. SAM Advanced Management Journal 61 (2): 11.

Lee, O.-K.D., et al. 2006. Aligning IT components to achieve agility in globally distributed system development. Communications of the ACM 49 (10): 48-54.

López, M.V., et al. 2007. Sustainable development and corporate performance: A study based on the Dow Jones sustainability index. Journal of Business Ethics 75 (3): 285-300.

Made in Free World. Available online: https://madeinafreeworld.com/ (Accessed: 15 May 2018).

Maden, C., et al. 2012. Linking corporate social responsibility to corporate reputation: A study on understanding behavioral consequences. Procedia-Social and Behavioral Sciences 58: 655-664.

Maignan, I., et al. 2002. Managing socially-responsible buying:: How to integrate non-economic criteria into the purchasing process. European Management Journal 20 (6): 641-648.

Manyika, J., et al. (2011). "Big data: The next frontier for innovation, competition, and productivity.".

Marshall, D., L. McCarthy, C. Heavey, and P. McGrath. 2015. Environmental and social supply chain management sustainability practices: Construct development and measurement. Production Planning \& Control 26 (8): 673-690.

Matten, D., and A. Crane. 2005. Corporate citizenship: Toward an extended theoretical conceptualization. Academy of Management Review 30 (1): 166-179.

Meidinger, E. 2017. The administrative law of global private-public regulation: The case of forestry. In Crime and regulation, 113-153. Routledge.

Mena, S., and G. Palazzo. 2012. Input and output legitimacy of multi-stakeholder initiatives. Business Ethics Quarterly 22 (3): 527-556.

Morais, D.O., and B.S. Silvestre. 2018. Advancing social sustainability in supply chain management: Lessons from multiple case studies in an emerging economy. Journal of Cleaner Production 199: 222-235.

Moreira, A.C., et al. 2018. Innovation and supply chain management: Relationship, collaboration and strategies. Springer.

Mueller, M., et al. 2009. The contribution of environmental and social standards towards ensuring legitimacy in supply chain governance. Journal of Business Ethics 89 (4): 509-523.

Muhtaroglu, F. C. P., et al. (2013). Business model canvas perspective on big data applications. Big Data, 2013 IEEE International Conference on, IEEE.

Murphy, P.R., and R.F. Poist. 2002. Socially responsible logistics: An exploratory study. Transportation Journal: 23-35. 
Newholm, T., and D. Shaw. 2007. Studying the ethical consumer: A review of research. Journal of Consumer Behaviour: an international research review 6 (5): 253-270.

Norton, T., et al. 2014. A guide to traceability: A practical approach to advance sustainability in global supply chains. New York, NY, USA: United Nations Global Compact Office.

Opara, L.U. 2003. Traceability in agriculture and food supply chain: A review of basic concepts, technological implications, and future prospects. Journal of Food Agriculture and Environment 1: 101-106.

Pagell, M., and Z. Wu. 2009. Building a more complete theory of sustainable supply chain management using case studies of 10 exemplars. Journal of Supply Chain Management 45 (2): 37-56.

Parker, G. G., et al. (2016). Platform revolution: How networked markets are transforming the Economyand how to make them work for you, WW Norton \& Company.

Pelsmacker, P.D., et al. 2006. Fair-trade beliefs, attitudes and buying behaviour of Belgian consumers. International Journal of Nonprofit and Voluntary Sector Marketing 11 (2): 125-138.

Pilkington, M. 2016. Blockchain technology: Principles and applications. In In: Olleros, F. X., \& Zhegu, M. (Eds.). (2016). Research handbook on digital transformations. Edward Elgar publishing.

Pogge, T. W. (2008). World poverty and human rights, Polity.

Quarshie, A.M., et al. 2016. Sustainability and corporate social responsibility in supply chains: The state of research in supply chain management and business ethics journals. Journal of Purchasing and Supply Management 22 (2): 82-97.

Rangi, S. et al. (2015). "How Globalisation Is Changing Research Agendas, Activities and Assessment Procedures within Research \& Innovation”. SATORI Project. Available online: http://satoriproject. eu/media/D3.3_legal_aspects_globalisation.pdf (Accessed: 12 January 2018)

Reuters (2018). "Blockchain to track Congo's cobalt from mine to mobile". Available online: https://www. cnbcafrica.com/news/2018/02/02/blockchain-track-congos-cobalt-mine-mobile/ (Accessed: 15 May 2018).

Ritvala, T., et al. 2014. MNCs and local cross-sector partnerships: The case of a smarter Baltic Sea. International Business Review 23 (5): 942-951.

Roberts, S. 2003. Supply chain specific? Understanding the patchy success of ethical sourcing initiatives. Journal of Business Ethics 44 (2-3): 159-170.

Ruggie, J.G. 2004. Reconstituting the global public domain-Issues, actors, and practices. European Journal of International Relations 10 (4): 499-531.

Russom, P. 2011. Big data analytics. TDWI best practices report, fourth quarter 19 (4): 1-34.

SAP, Cloud Platform. Available online: https:/cloudplatform.sap.com/index.html (Accessed: 15 May 2018).

Scherer, A.G. 2018. Theory assessment and agenda setting in political CSR: A critical theory perspective. International Journal of Management Reviews 20 (2): 387-410.

Scherer, A.G., A. Rasche, G. Palazzo, and A. Spicer. 2016. Managing for political corporate social responsibility: New challenges and directions for PCSR 2.0. Journal of Management Studies 53 (3): 273-298.

Schoenherr, T., and C. Speier-Pero. 2015. Data science, predictive analytics, and big data in supply chain management: Current state and future potential. Journal of Business Logistics 36 (1): 120-132.

Scott, C. (2010). Reflexive governance, regulation and meta-regulation: Control or learning? De Schutter, O. and Lenoble, J.(eds.). Reflexive Governance, Hart Publishing: 43-66.

Scott, C., et al. 2011. The conceptual and constitutional challenge of transnational private regulation. Journal of Law and Society 38 (1): 1-19.

Sedex Global (a). "About Sedex." Available online: http://www.sedexglobal.com/about-sedex/ (Accessed 20 May 2018).

Sedex (b) (2015). "Sedex annual review 2013/14: Bringing transparency to global, multi-tier supply chains." Internal document provided by Sedex.

Sedex (c). "Sedex Members." Available online: http://www.sedexglobal.com/about-sedex/members/ (Accessed: 20 May 2018).

Sedex (d). "What we do." Available online: http://www.sedexglobal.com/about-sedex/what-we-do/ (Accessed: 20 May 2018).

Sedex (e). "Risk Assessment." Available online: http://www.sedexglobal.com/member-services/risk-assessment/ (Accessed: 20 May 2018).

Sedex (f). "Ethical audits: SMETA". Available online: http://www.sedexglobal.com/ethical-audits/smeta/ (Accessed: 20 May 2018).

Sedex (g). (2013) "Fire Safety briefing". Available online: https://www.sedexglobal.com/briefing-fire-safety/. Accessed 10 May 2019

Sedex (h). (2018) "Sedex supplier workbook". Available online, requires registration: https://www.sedexglobal. com/our-services/supplier-workbook/. Accessed 10 May 2019

Sedex (i). "Sedex SMETA in numbers". Available online: https://cdn.sedexglobal.com/wp-content/uploads/2017 /08/SMETA-in-Numbers.pdf (Accessed: 20 May 2018). 
Sedex (2017). "Sedex stakeholder Forum (SSF) - Manchester summary." Available online: https://www. sedexglobal.com/sedex-stakeholder-forum-manchester-summary/ (Accessed: 20 May 2018).

Seuring, S., and M. Müller. 2008a. Core issues in sustainable supply chain management-a Delphi study. Business Strategy and the Environment 17 (8): 455-466.

Seuring, S., and M. Müller. 2008b. From a literature review to a conceptual framework for sustainable supply chain management. Journal of Cleaner Production 16 (15): 1699-1710.

Sharfman, M.P., T.M. Shaft, and R.P. Anex Jr. 2009. The road to cooperative supply-chain environmental management: Trust and uncertainty among pro-active firms. Business Strategy and the Environment 18 (1): $1-13$.

Shen, W., and D.H. Norrie. 1999. Agent-based systems for intelligent manufacturing: A state-of-the-art survey. Knowledge and Information Systems 1 (2): 129-156.

Shepherd, C., and Günter, H. 2006. "Measuring Supply Chain Performance: Current Research and Future Directions." International Journal of Productivity and Performance Management 55.3/4: 242-58. Web.

Stammer, R. (2016). "It pays to become a B corporation", Harvard Business Review, Available online: https:/hbr.org/2016/12/it-pays-to-become-a-b-corporation (Accessed: 15 May 2018).

Stevenson, M., and M. Spring. 2007. Flexibility from a supply chain perspective: Definition and review. International Journal of Operations \& Production Management 27 (7): 685-713.

Strand, R. 2009. Corporate responsibility in Scandinavian supply chains. Journal of Business Ethics, 85(1), 179185

Suchanek, A. 2008. Business ethics and the golden rule. In Diskussionspapier des Wittenberg-Zentrums für Globale Ethik, 2008-2003.

Svensson, G. 2007. Aspects of sustainable supply chain management (SSCM): Conceptual framework and empirical example. Supply chain management: An international journal 12 (4): 262-266.

Tan, K.H., et al. 2015. Harvesting big data to enhance supply chain innovation capabilities: An analytic infrastructure based on deduction graph. International Journal of Production Economics 165: 223-233.

Tapscott, D., and A. Tapscott. 2016. Blockchain revolution: How the technology behind bitcoin is changing money, business, and the world. Penguin.

Tencati, A., and L. Zsolnai. 2009. The collaborative enterprise. Journal of Business Ethics 85 (3): 367-376.

Teubner, G. 1997. Breaking frames: The global interplay of legal and social systems. JSTOR.

UN Human Rights Council (2008). Protect, respect and remedy: a framework for business and human rights : report of the Special Representative of the Secretary-General on the Issue of Human Rights and Transnational Corporations and Other Business Enterprises, John Ruggie, 7 April 2008, A/HRC/8/5; UN (2011). Guiding principles on business and human rights: Implementing the United Nations "Protect, Respect and Remedy" framework

UNGC (2015). "Supply chain sustainability - a practical guide for continuous improvement.", Second Edition. Available online: https://www.unglobalcompact.org/docs/issues_doc/supply_chain/SupplyChainRep_ spread.pdf (Accessed: 10 January 2018).

UNGC Australia. "Supply chain sustainability". Available online: http://www.unglobalcompact.org. $\mathrm{au} /$ issues/embedding-and-implementing-sustainability/supply-chain-sustainability (Accessed: 10 January 2018).

Utting, P. (2002). "Regulating business via multistakeholder initiatives: A preliminary assessment." Voluntary approaches to corporate responsibility: Readings and a resource guide $\mathbf{6 1 1 3 0 .}$

Van Huijstee, M., and P. Glasbergen. 2010. Business-NGO interactions in a multi-stakeholder context. Business and Society Review 115 (3): 249-284.

Van Opijnen, M., and J. Oldenziel. 2011. Responsible supply chain management: Potential success factors and challenges for addressing prevailing human rights and other CSR issues in supply chains of EU-based companies. In Centre for Research of multinational corporations, European union.

Vurro, C., et al. 2009. Shaping sustainable value chains: Network determinants of supply chain governance models. Journal of Business Ethics 90 (4): 607-621.

Walker, D. H. and L. Bourne (2007). Stakeholders and the supply chain. Procurement Systems, Routledge: 94 124.

Waller, M.A., and S.E. Fawcett. 2013. Data science, predictive analytics, and big data: A revolution that will transform supply chain design and management. Journal of Business Logistics 34 (2): 77-84.

Wamba, S.F., et al. 2015. How 'big data'can make big impact: Findings from a systematic review and a longitudinal case study. International Journal of Production Economics 165: 234-246.

Wang, G., et al. 2016. Big data analytics in logistics and supply chain management: Certain investigations for research and applications. International Journal of Production Economics 176: 98-110.

Wettstein, F. 2012. Silence as complicity: Elements of a corporate duty to speak out against the violation of human rights. Business Ethics Quarterly 22 (1): 37-61. 
Wettstein, F. 2015. Normativity, ethics, and the UN guiding principles on business and human rights: A critical assessment. Journal of Human Rights 14 (2): 162-182.

Wolf, J. 2011. Sustainable supply chain management integration: A qualitative analysis of the German manufacturing industry. Journal of Business Ethics 102 (2): 221-235.

Wood, D.J. 1991. Corporate social performance revisited. Academy of Management Review 16 (4): 691-718.

Wold Economic Forum (2018). "Blockchain beyond the hype a practical framework for business leaders", White Paper. Available online: http://www3.weforum.org/docs/48423_Whether_Blockchain_WP.pdf (Accessed: 15 May 2018).

Wu, Z., and M. Pagell. 2011. Balancing priorities: Decision-making in sustainable supply chain management. Journal of Operations Management 29 (6): 577-590.

WWF Global (2018). "New Blockchain project has potential to revolutionise seafood industry". Available online: http://wwf.panda.org/wwf_news/?320232/New-Blockchain-Project-has-Potential-to-RevolutioniseSeafood-Industry (Accessed: 15 May 2018).

Xu, J.J. 2016. Are blockchains immune to all malicious attacks? Financial Innovation 2 (1): 25.

Yli-Huumo, J., D. Ko, S. Choi, S. Park, and K. Smolander. 2016. Where is current research on blockchain technology?-A systematic review. PLoS One 11 (10): e0163477.

Zadek, S. 2004. The path to corporate responsibility. Harvard Business Review 82 (12): 125-133.

Zhou, H., et al. 2014. Supply chain practice and information quality: A supply chain strategy study. International Journal of Production Economics 147: 624-633.

Zink, K.J., and K.J. Zink. 2008. Corporate sustainability as a challenge for comprehensive management. Springer.

Publisher's Note Springer Nature remains neutral with regard to jurisdictional claims in published maps and institutional affiliations.

Ms. Gurzawska is a PhD Candidate at the Department of Philosophy, University of Twente. She has worked on a number of projects funded by the European Commission, including SATORI (Stakeholders Acting Together On the ethical impact assessment of Research and Innovation), Responsible Industry and SHERPA Project. Ms. Gurzawska holds an M.A. in Law from the University of Lodz and an M.A. in Human Rights and Democratisation from the European Inter-University Centre for Human Rights and Democratisation (E.MA.). Her main research areas include international law, in particular human rights and business; corporate social responsibility (CSR); strategic CSR; ethics of technology; and responsible innovation and new technologies in the business context. In her career, Ms. Gurzawska has cooperated with Danish Institute for Human Rights (Copenhagen), Helsinki Foundation for Human Rights (Warsaw), Centre for Business, Organisations \& Society (University of Bath) and 4TU.Centre for Ethics and Technology (The Netherlands). 